THE KURUME MEDICAL JOURNAL

Vol. 24, No.3, p. 191-197, 1977

\title{
DISTRIBUTION OF THE GLYCOSAMINOGLYCANS IN THE ABDOMINAL WALLS OF THE RATS
}

\author{
HIROSHI MASUDA, SHIGEKI SHICHIJO AND MUTSUYA TAKEUCHI \\ Institute of Clinical Pathology, Kurume University School of Medicine, \\ Kurume, 830, Japan
}

\author{
TOMOYOSHI GOYA, MURAJI HIRAI AND HIDERO NAKAZONO \\ First Department of Internal Medicine, Kurume University \\ School of Medicine, Kurume, 830, Japan
}

(Received for publication July 25, 1977)

\begin{abstract}
A study has been made of the glycosaminoglycans and glycopeptide in the abdominal walls of the rats. The abdominal walls were separated into three layers; dermis, adipose tissue and muscle containing fascia, and then uronic acid, sulfate, hexose and sialic acid contents were measured in each layer. Values per $g$ of wet tissue were highest in the skin, whereas those of dry tissue were highest in the adipose tissue. Cellulose acetate strip-electrophoresis of materials in barbital buffer revealed the presence of three alcian blue positive fractions in every layer. The relative proportions of the fractions which corresponded in mobility to hyaluronic acid, to heparan sulfate and to chondroitin sulfates were approximately $40 \%$, $10 \%$ and $50 \%$, respectively.
\end{abstract}

\section{INTRODUCTION}

Glycosaminoglycans and glycopeptide in the skins of both men and rats have well been studied by many authors (Fabianek and Herp, 1966 ; Tanaka, 1967 ; Shetlar et al., 1972), and different values were obtained between the skins of these two different species of animals. At present, however, little is known about these substances in other layers of the abdominal walls of rats. Previous study have demonstrated the distribution of the glycosaminoglycans and glycopeptide in the different layers of the human abdominal walls (Masuda et al., 1977). The present paper deals with a demonstration of these substances in the different layers of the abdominal walls of rats.

\section{MATERIALS AND METHODS}

\section{Materials}

Five adult male Wistar rats weighing from 365 to $520 \mathrm{~g}$, average $452 \mathrm{~g}$ were used. The abdominal walls were separated into three layers ; skin, adipose tissue and muscle including fascia. The samples were cut into cherry-sized pieces, put into several changes of acetone for several days and dried in a desiccator over $\mathrm{CaCl}_{2}$. They were 
ground in a Wiley mill, sufficiently small to pass through a 60 mesh sieve. All tissues were treated similarly and compared with one another.

Isolation of the crude giycosaminoglycans and glycopeptide from the abdominal wall tissues

The crude glycosaminoglycans and glycopeptide were extracted from these dry tissues according to the procedure of Schiller et al. (1961) as shown in Fig. 1. These were digested with $1 / 50$ weights of papain (EC 3.4.4.10) in the presence of EDTA and cysteine (5:9: 4 , w/w/w) at $65^{\circ} \mathrm{C}$ for $48 \mathrm{hr}$. The mixture was adjusted to $\mathrm{pH} 7.8$ and then digested with $1 / 50$ weights of trypsin

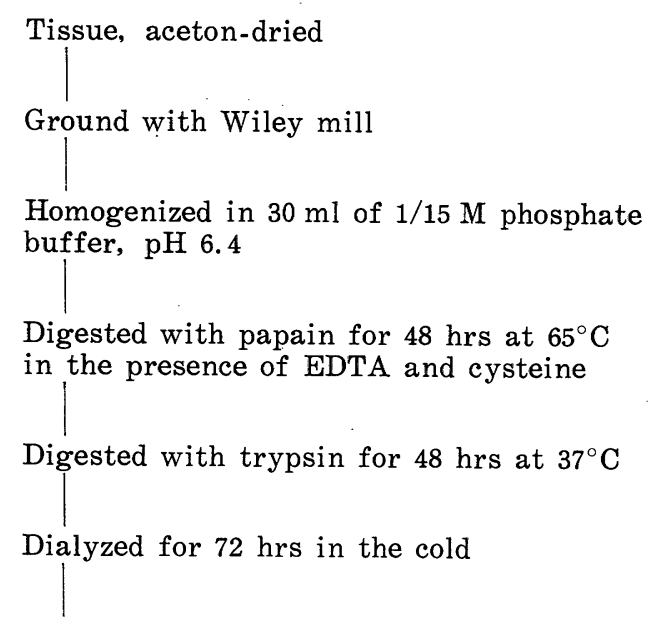

Precipitated with adding 4 volume of $95 \%$ alcohol (containing $1 \%$ acetic acid and $1 \%$ $\mathrm{K}$-acetate)

Washed with $80 \%$ alcohol and air-dry

Dissolved with deionized water (A mixture of the Glycosaminoglycan and Glycopeptide)

Fig. 1 Isolation of the glycosaminoglycan and glycopeptide from the abdominal wall tissues.
(EC 3.4.4.4) at $37^{\circ} \mathrm{C}$ for $48 \mathrm{hr}$ with simultaneous dialysis against $0.1 \mathrm{M}$ phosphate buffer of $\mathrm{pH}$ 7.8. The digested solution was deproteinized with $5 \%$ trichloroacetic acid in the cold and the supernatant was dialyzed against several changes of the cold deionized water for $72 \mathrm{hr}$. Then 4 volumes of alcohol containing $1 \%$ acetic acid and $1 \%$ potassium acetate were added in order to precipitate the crude glycosaminoglycans and glycopeptide. The precipitate was washed with alcohol, dried in a desiccator over $\mathrm{CaCl}_{2}$ and then redissolved in $5 \mathrm{ml}$ of deionized water. An aliquot was used for hexose, sialic acid, uronic acid and sulfate analyses as well as for cellulose acetate electrophoresis. Uronic acid measurement was also tried in the dialysate in the isolation procedure of the crude glycosaminoglycans and glycopeptide.

\section{Analytical procedures}

Uronic acid content was determined by carbazole reaction of Dische, using glucuronic acid as a standard (Dische, 1962), and sulfate content by the Dodgson-Price's method after hydrolysis in $4 \mathrm{~N} \mathrm{HCl}$ for $6 \mathrm{hr}$ at $100^{\circ} \mathrm{C}$ in the sealed ampoule, with chondroitin-4-sulfate as a standard (Dodgson and Price, 1962). Hexose content was estimated by orcinol-sulfuric acid method of Winzler, utilizing a mixture of mannose and galactose as a standard (Winzler, 1955a) and sialic acid content by Winzler's diphenylamine method, using $\mathrm{N}$-acetylneuraminic acid as a standard (Winzler, 1955 b), respectively.

\section{Electrophoresis of glycosaminoglycan on a cellulose acetate strip}

The material was run in a horizontal 
type apparatus at a constant current of $1.0 \mathrm{~mA} / \mathrm{cm}$ on an OXOID strip $(9 \times$ $1.2 \mathrm{~cm}$ ) using both barbital buffer, $\mathrm{pH}$ 8. $6, \mu=0.06$ for $30 \mathrm{~min}$ and $0.3 \mathrm{M}$ calcium acetate electrolyte, $\mathrm{pH} 7.5$ for 180 min. 5 to $10 \mu$ l of aqueous suspensions of preparations in $10 \mathrm{mg}$ per $0.1 \mathrm{ml}$ were used in this study. After electrophoresis, the strip was stained with alcian blue in the normal way with hyaluronic acid, heparan sulfate, chondroitin-4-sulfate, chondroitin-6-sulfate and dermatan sulfate as standards: hyaluronic acid, chondroitin-4-sulfate and chondroitin-6-sulfate were purchased from Seikagaku Kogyo Co., Ltd. (Tokyo, Japan), and heparan sulfate and dermatan sulfate were kindly given by Dr. A. Cifonelli (Chicago University, U.S.A.) and Dr. Y. Tanaka (Kurume University, Japan), respectively. Hyaluronic acid was derived from human umbilical cord, heparan sulfate from bovine liver, chondroitin-4-sulfate and chondroitin-6-sulfate from whale cartilage and dermatan sulfate from swine skin, respectively. After the strip was stained with alcian blue, it was scanned in Atago Densitometer (Tokyo, Japan) in the normal way.

\section{RESULTS AND DISCUSSION}

Both the wet skin and the wet muscle including fascia of rats contained on averages of $24 \%$ of dry defatted material, whereas the wet adipose tissue of animals averaged $4 \%$.

Results of the uronic acid, sulfate, hexose and sialic acid analyses of the glycosaminoglycans and glycopeptide in the different layers of the abdominal walls are summarized in Table 1 . Values per $\mathrm{g}$ of wet tissue were all highest in the dermis and lowest in the muscle including the fascia, while those per $\mathrm{g}$ of dry tissue were all highest in the adipose tissue. Concerning the uronic acid content in the skin of the rat, our value are almost agreed with the data of Fabianek and Herp (1966); they reported that the dermis of the rat contained $839 \pm 96 \mu \mathrm{g}$ (averages \pm standard deviations) of uronic acid per $\mathrm{g}$ of dry defatted material. The content of glycosaminoglycans in the rat skin was almost equal to that in the human skin which reported previously (Masuda et al., 1977), whereas the concentration of the glycopeptide were $50 \%$ to $70 \%$ lower for the rat skin as compared to

TABLE 1

Glycosaminoglycan and glycopeptide contents in the abdominal walls of the normal rat ${ }^{\text {a) }}$

\begin{tabular}{|c|c|c|c|c|c|c|c|c|}
\hline \multirow[b]{2}{*}{ Subject } & \multicolumn{2}{|c|}{ Uronic acid } & \multicolumn{2}{|c|}{ Sulfate } & \multicolumn{2}{|c|}{ Hexose } & \multicolumn{2}{|c|}{ Sialic acid } \\
\hline & $\begin{array}{l}\mu \mathrm{g} / \mathrm{wet} \\
\text { tissue* }\end{array}$ & $\begin{array}{l}\mu \mathrm{g} / \mathrm{dry} \\
\text { tissue }\end{array}$ & $\begin{array}{l}\mu \mathrm{g} / \text { wet } \\
\text { tissue }\end{array}$ & $\begin{array}{l}\mu \mathrm{g} / \mathrm{dry} \\
\text { tissue }\end{array}$ & $\begin{array}{l}\mu \mathrm{g} / \text { wet } \\
\text { tissue }\end{array}$ & $\begin{array}{l}\mu \mathrm{g} / \mathrm{dry} \\
\text { tissue }\end{array}$ & $\begin{array}{l}\mu \mathrm{g} / \text { wet } \\
\text { tissue }\end{array}$ & $\begin{array}{l}\mu \mathrm{g} / \mathrm{dry} \\
\text { tissue }\end{array}$ \\
\hline Skin & $138 \pm 15.4$ & $570 \pm 66.5$ & $35 \pm 6.1$ & $144 \pm 34.8$ & $130 \pm 15.9$ & $535 \pm 39.4$ & $38 \pm 3.5$ & $158 \pm 22.5$ \\
\hline Adipose tissue & $27 \pm 15.2$ & $675 \pm 319.3$ & $6 \pm 1.3$ & $166 \pm 11.3$ & $40 \pm 9.3$ & $1066 \pm 88.7$ & $10 \pm 4.1$ & $252 \pm 71.7$ \\
\hline $\begin{array}{l}\text { Muscle including } \\
\text { fascia }\end{array}$ & $47 \pm 6.0$ & $201 \pm 26.2$ & $9 \pm 3.3$ & $37 \pm 14.9$ & $69 \pm 8.1$ & $293 \pm 36.4$ & $12 \pm 2.6$ & $53 \pm 11.6$ \\
\hline
\end{tabular}

a) Results given are average of 5 samples. Figures following \pm sign are standard deviations.

* $\mu \mathrm{g} / \mathrm{g}$ of wet tissue.

** $\mu \mathrm{g} / \mathrm{g}$ of dry tissue. 
(a)

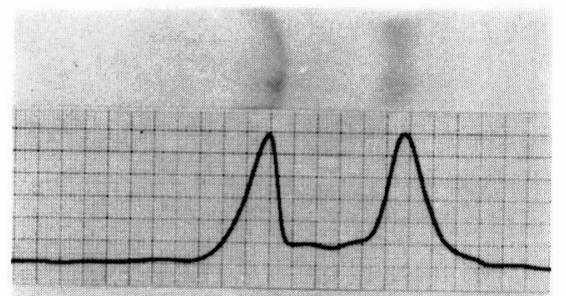

(b)

(c)
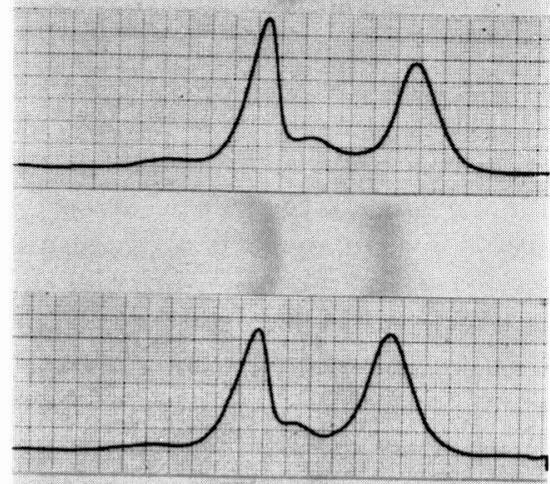

(d)

(e)

(f)

$$
\left.(-)\right|_{0} ^{\uparrow}
$$

the human skin. This may be attributable to the difference of the species. Uronic acid measurement was also tried in the outside solution of the dialyzing bag in the isolation procedure of the crude glycosaminoglycans and glycopeptide; the dialysate had no detectable amount of uronic acid.

Cellulose acetate strip-electrophoresis of concentrates in barbital buffer revealed the presence of three alcian blue positive fractions in every case, numbered in order of increasing electrophoretic mobility, Fr. I, Fr. II and
Fig. 2 Electrophoretic patterns and their densitograms of marker samples and abdominal wall tissue glycosaminoglycans in barbital buffer, $\mathrm{pH} 8.6, \mu=0.06$. Electrophoretic migration is from left to right.

(a) skin, (b) subcutaneous adipose tissue, (c) Musculus rectus abdominis including fascia, (d) standard containing hyaluronic acid, (c) standard containing heparan sulfate, (f) standards containing chondroitin-4-sulfate, chondroitin-6-sulfate and dermatan sulfate.

Fr. III. The fraction I corresponded in mobility with hyaluronic acid ; the fraction II corresponded in mobility with heparan sulfate; the fraction III corresponded in mobility with chondroitin4-sulfate, chondroitin-6-sulfate and dermatan sulfate (Fig. 2).

The relative proportions of the fraction I, fraction II and fraction III are summarized in Table 2. The proportion of the fraction I was approximately $40 \%$ of total glycosaminoglycans, that of the fraction II was approximately 10 $\%$ and that of the fraction III was ap- 
TABLE 2

Relative proportions of fraction $I$, II and III on cellulose acetate strip-electrophoresis in barbital buffer of the normal abdominal walls ${ }^{\mathrm{a}}$

\begin{tabular}{c|c|c|c}
\hline Subject & Fraction I & Fraction II & Fraction III \\
\hline Skin & $38.0 \pm 0.59$ & $10.0 \pm 0.90$ & $51.1 \pm 0.51$ \\
Adipose tissue & $39.7 \pm 6.61$ & $13.6 \pm 2.01$ & $46.5 \pm 4.43$ \\
Muscle including fascia & $41.5 \pm 1.00$ & $8.1 \pm 1.30$ & $50.4 \pm 2.13$ \\
\hline
\end{tabular}

a) Results given are averages of 5 samples; values are expressed in $\%$. Figures following \pm sign are standard deviations.

proximately $50 \%$ in every tissue, respectively; no remarkable difference was observed among these three different layers of the abdominal walls. These findings differ from those of the human abdominal walls reported previously by the authors who found interesting alterations with layers; the proportion of the fraction I was almost equal to that of the fraction III in the skin as well as in the adipose tissue, and the proportion of the fraction I was highest in the muscle, whereas that of the fraction III was highest in the fascia. This may be due to the different experimental design used by the authors; the abdominal walls of the rat were separated into three layers of the skin, adipose tissue and muscle including facia in the present report, while the human abdominal walls were separated into four layers of the dermis, adipose tissue, muscle and fascia in the previous report. Fabianek and Herp (1966) reported that $49 \pm 5.3 \%$ (averages \pm standard errors) of all glycosaminoglycans were hyaluronic acid, $47 \pm 5 \%$ were chondroitin sulfates and $4 \pm 1.9 \%$ were heparin, respectively.
Cellulose acetate strip-electrophoresis of materials in $0.3 \mathrm{M}$ calcium acetate electrolyte resulted in two components which corresponded in mobility with hyaluronic acid, and with heparan sulfate and dermatan sulfate in every tissue, respectively. But the skin material had no detectable amount of the fraction which corresponded in mobility with chondroitin-4-sulfate and chondroitin-6-sulfate in this electrolyte (Fig. 3). The findings are quite different from the reports on glycosaminoglycans composition in the skin of rat.

Hardingham and Phelps (1970) reported that the rat skin consisted of six kinds of glycosaminoglycans; hyaluronic acid $(56 \%)$, dermatan sulfate $(15.6 \%)$, chondroitin-6-sulfate $(9.1 \%)$, chondroitin 4-sulfate, heparan sulfate and heparin. This difference in glycosaminoglycans composition in the rat skin and the biological significance are not clear. Further investigation will be necessary to isolate and identificate the each glycosaminoglycan from the different layers of the abdominal walls of the rat. 
(a)

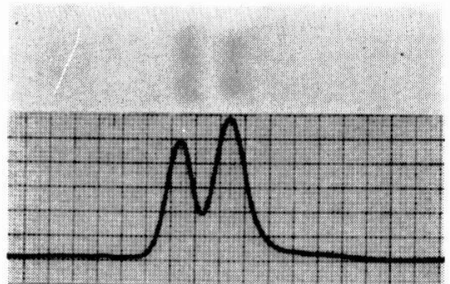

(b)

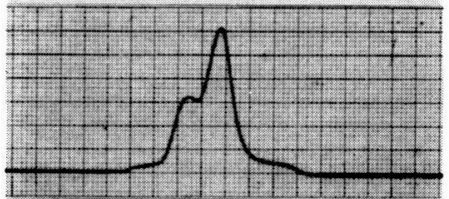

(c)

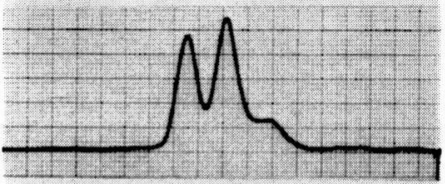

(d)

(e)

(f)

(g)

(h)

$$
(-) \uparrow
$$

Fig. 3 Electrophoretic patterns and their densitograms of marker samples and abdominal wall tissue glycosaminoglycans in 0.3 $\mathrm{M}$ calcium acetate electrolyte, $\mathrm{pH}$ 7.5. Electrophoretic migration is left to right.

(a) skin, (b) subcutaneous adipose tissue, (c Musculus rectus abdominis including fascia, (d) standard containing hyaluronic acid, (e standard containing heparan sulfate, (f) standard containing dermatan sulfate, (g) standard containing condroitin-4-sulfate, (h) standard containing condroitin-6-sulfate. 


\section{REFERENCES}

Dische, Z. (1962). In "Methods in Carbohydrate Chemistry" (R. L. Whistler and M. L. Wolform, eds.), Vol. 1, pp. 477-500. Academic Press Inc., New York, New York.

Dodgson, K.S. and PRICE, R.G. (1962). Determination of inorganic sulfate in studies on the enzymic and non-enzymic hydrolysis of carbohydrate and other sulphate esters. Biochem. J., 84, 106-112.

FabianeK, J. and Herp, A. (1966). Glycoprotein and collagen metabolism in the dermis of hypophysectomized rats. Endocrinology, 78, 1255-1258.

Hardingham, T. E. and Phelps, C. F. (1970). The glycosaminoglycans of neonatal rat skin. Biochem. J., 117, 813-818.

Masuda, H., Shichi jo, S. and Takeuchi, M. (1977). Comparative studies on the distribution of the glycopeptide and glycosaminoglycans in the human abdominal walls. Int. J. Biochem., 8 (in press).

Schiller, S., Slover, G. A. and Dorfmann, A. (1961). A method for the separation of acid mucopolysaccharides; its application to the isolation of heparin from the skin of rats. J. Biol. Chem., 236, 983-990.

Shetlar, M. R, Shetlar, C. L. Chien, S. F, Linares, H., Dobrkovsky, M. and Larson, D. L. (1972). The hypertrophic scar. Hexosamine containing components of burn scars. Proc. Soc. Exptl. Biol. Med, 139, 544-547.

TANAKA, Y. (1967). Acid mucopolysaccharides and glycoproteins in the skin. J. Kurume Med. Assoc., 30, 899-908.

WinZLER, R. L. (1955 a). In "Methods of Biochemical Analysis" (D. Glick, ed.), II, pp. 279-268. Interscience Publishers, New York. WINZLER, R. J. (1955 b). In "ibid.", 298-306, ibid., New York. 